\title{
On the Induction of Zoosporogenesis in the Rumen Phycomycetes Neocallimastix frontalis, Piromonas communis and Sphaeromonas communis
}

\author{
By COLIN G. ORPIN \\ Biochemistry Department, Agricultural Research Council, Institute of Animal Physiology, \\ Babraham, Cambridge CB2 $4 A T$
}

(Received 23 March 1977)

\begin{abstract}
The plant components inducing zoosporogenesis in the rumen phycomycetes Neocallimastix frontalis, Sphaeromonas communis and Piromonas communis were widely distributed in the plant kingdom with no apparent taxonomic relationship. In Lolium perenne $\mathrm{L}$. (perennial rye-grass) and Hordeum distichon (barley), the components were principally present in the leaves and aerial tissues. Sufficient inducer was present in the normal diet of the host animal to trigger the differentiation and release of the zoospores from all the sporangia of each phycomycete species present in the rumen fluid tested. The inducers were unstable to oxygen, especially at elevated temperatures, and were destroyed by rumen micro-organisms. They may be similar compounds for each species.
\end{abstract}

\section{INTRODUCTION}

The flagellates Neocallimastix frontalis, Sphaeromonas communis and Piromonas communis are the zoospores of three species of phycomycete fungi inhabiting the rumen (Orpin, 1975, 1976, 1977b,c). The zoospores are released from the sporangia, borne on the vegetative stage of each species, in response to a component in the diet of the host animal. The dietary components responsible for the initiation of differentiation within the sporangia and liberation of the zoospores have not yet been characterized. This paper reports the distribution and relative abundance of these components in different plants and plant tissues, and investigates their longevity in the diet and stability in vitro and in the rumen.

\section{METHODS}

Animals. The sheep used were Clun Forest wethers, each fitted with a permanent rumen cannula. Defaunation was by the method of Abou Akkada et al. (1968) using dioctyl sodium sulphosuccinate, except that food was withdrawn on the day dioctyl sulphosuccinate was administered and I $\mathrm{kg}$ hay was fed on the next day. Normal feeding was resumed on the third day. All rumen phycomycetes were removed using actidione (Orpin, $1977 a$ ). Populations of individual species of rumen phycomycetes were established by adding to the rumen (free of phycomycetes) $500 \mathrm{ml}$ cultures of the particular species grown in vitro (Orpin, 1975, 1976, 1977 b). After 7 to 20 days the population density of each species stabilized. Sheep could be maintained in this state for up to 5 weeks provided precautions were taken to avoid contact between sheep and the transfer of bedding and feeding bins.

Diet. The standard diet was I $\mathrm{kg}$ hay chaff and $100 \mathrm{~g}$ rolled oats, fed once daily.

Rumen fluid fractions. Rumen fluid, obtained by aspiration through the rumen cannula 17 to $20 \mathrm{~h}$ after feeding, was filtered through one layer of muslin; the filtrate was designated fresh rumen fluid (FRF). Part of this fraction was autoclaved $\left(115^{\circ} \mathrm{C}, 20 \mathrm{~min}\right.$ ). The remainder was centrifuged at $1000 \mathrm{~g}$ for $15 \mathrm{~min}$ to remove the protozoa, large bacteria, flagellates and plant debris. The sediment was washed three times by centrifuging in sterile reduced CRF (see below) and resuspended in the original volume of sterile 
reduced CRF. This fraction was designated the large particulate fraction. The supernatant from the first centrifugation at $1000 \mathrm{~g}$ was centrifuged at $38000 \mathrm{~g}$ for $\mathrm{I} \mathrm{h}$ at $4{ }^{\circ} \mathrm{C}$ to sediment the bacteria and small particles, and the pellet was washed twice by centrifuging under the same conditions with sterile reduced CRF (see below); the washed pellet was designated the bacterial fraction. The supernatant from the first centrifugation at $38000 \mathrm{~g}$ was usually clear; it was designated centrifuged rumen fluid (CRF). This was autoclaved ( $115{ }^{\circ} \mathrm{C}, 20 \mathrm{~min}$ ) to yield sterile CRF. Reduced CRF was prepared by aseptically adding $5 \mathrm{ml}$ sterile $2 \%(\mathrm{w} / \mathrm{v})$ L-cysteine hydrochloride (neutralized immediately before use with I $\mathrm{M}-\mathrm{NaOH}$ ) to each I00 $\mathrm{ml}$ sterile CRF.

Isolation of 'inducer' fraction from oats. The methods were those used by Orpin (I974) to obtain a fraction stimulatory to sporogenesis in $N$. frontalis. The aqueous fraction was extracted with 3 vols of peroxide-free diethyl ether, and the ether extract was evaporated to a small volume and taken up in acetone. The final extract contained material from $10 \mathrm{~g}$ dry wt oats $\mathrm{ml}^{-1}$, and was stored under $\mathrm{N}_{2}$ at $-20^{\circ} \mathrm{C}$. This extract was used as the 'inducer' throughout except where indicated. It contained inducers which stimulated sporogenesis in all three species of rumen phycomycetes. Since the activity of the inducers varied between batches of oats and decreased with the storage time of the oats (see Results), a single extract from one batch of oats was used as reference material; when stored at $-20^{\circ} \mathrm{C}$ under $\mathrm{N}_{2}$ no loss of inducing capacity was detected in 9 months.

Sources of plant material. Barley (Hordeum distichon) plants were supplied by Mr K. Hansen, Agricultural Research Council Plant Breeding Institute, Trumpington, Cambridge. Other material was obtained from within the grounds of the laboratories.

Release of inducers from plant tissue by homogenization. Leaves of Lolitim perenne L. (I.5 g dry wt), harvested before inflorescence formation, were cut into small pieces and homogenized for $2 \mathrm{~min}$ in $50 \mathrm{ml}$ distilled water using an Ultra-turrax homogenizer. The homogenate was filtered, the filter was washed with $20 \mathrm{ml}$ distilled water and the filtrate was centrifuged at $38000 \mathrm{~g}$ for $30 \mathrm{~min}$ at $4{ }^{\circ} \mathrm{C}$. The pellet was washed with $20 \mathrm{ml}$ water and the supernatants were combined to yield 'soluble material'. The pellet and leaf material on the filter were combined and designated 'insoluble material'. Eoth soluble and insoluble fractions and the complete homogenate were extracted as described below and assayed quantitatively for each inducer.

Exiraction of inducers from plant material other than oats. The plant material was cut into $\mathrm{I} \mathrm{cm}$ lengths, dried at $39{ }^{\circ} \mathrm{C}$ to constant weight and $1.0 \mathrm{~g}$ portions were extracted with $20 \mathrm{ml} 80 \%(\mathrm{v} / \mathrm{v})$ aqueous acetone. The acetone was removed under reduced pressure and the aqueous phase was evaporated in vacuo until only a thick oil remained; this was taken up in acetone $(1.0 \mathrm{ml})$ and assayed for the presence of the inducers.

Assay of inducers. Since the identity of the inducers of sporogenesis in all three organisms has not been established, it was necessary to use a biological assay to locate the inducer in extracts of different plants and tissues; this method could also quantify each inducer relative to that present in a standard extract of oats. For the detection of inducer, $1.0 \mathrm{ml} F R F$ and $0.1 \mathrm{ml}$ test sample were incubated at $39{ }^{\circ} \mathrm{C}$ in a stoppered $\mathrm{CO}_{\mathrm{z}}$-gassed test tube. The population density of each flagellate was determined at the start of the experiment and after $30 \mathrm{~min}(N$. frontalis) or to min ( $S$. communis and $P$. communis) and compared with that in a control tube containing distilled water in place of the test sample. If a greater increase in the population density of flagellates was recorded in the experimental tube than in the control tube, the inducer for that species was regarded as being present. The quantity of each inducer in a sample was determined relative to that in the standard oats extract as follows. The sample was diluted until the number of flagellates released on incubation with FRF ranged from 10 to $100 \%$ of the maximum (those released in response to standard oats extract prepared from $100 \mathrm{mg}$ dry wt oats). A series of dilutions of the unknown extract were prepared around this dilution, and the number of flagellates released from the same FRF was plotted against each dilution; the curve was extrapolated to zero flagellate production. At high dilutions the number of flagellates produced was directly proportional to the concentration of the inducer present. The dilution at which flagellate production was zero was compared with the dilution of the standard oats extract which showed no inducing activity, arbitrarily fixed at 100.

Effect of heat, $\mathrm{pH}$ and gas phase on the activity of the inducer. Each inducer fraction, extracted from $0.2 \mathrm{~g}$ dry wt oats and taken up in $2 \mathrm{ml}$ distilled water, was subjected to ultrasonic treatment and maintained at $22{ }^{\circ} \mathrm{C}$ or $100{ }^{\circ} \mathrm{C}$ under a gas phase of air, $\mathrm{O}_{2}, \mathrm{~N}_{2}$, or $\mathrm{CO}_{2}$. The gas (saturated with water vapour) was bubbled through the extract for $5 \mathrm{~min}$ before incubation, and passed over the extract during the incubation. The $\mathrm{pH}$ was adjusted where necessary with $0.1 \mathrm{M}-\mathrm{HCl}$ or $0.1 \mathrm{M}-\mathrm{NaOH}$ and incubations were carried out at p. $44^{\circ}, 7^{\circ} \circ$ and $9^{\circ} \mathrm{O}$. At the end of the incubation $\left(5 \mathrm{~min}, \mathrm{I} \mathrm{h,} 4 \mathrm{~h}\right.$ or $8 \mathrm{~h}$ ) the $\mathrm{pH}$ was adjusted to $7^{\circ} \mathrm{O}$ where necessary and the extracts tested for their ability to induce the release of each species of flagellate using the m.ethods of Orpin $(1975,1976,1977 b)$. The population density change of each species of phycomycete flagellate was compared with that produced by untreated extract. 
Stability of inducer in the presence of rumen fluid. The stability of the inducer in the presence of different rumen fluid fractions was assessed using the following method. The inducer extracted from $0.3 \mathrm{~g} \mathrm{dry} \mathrm{wt}$ oats was placed in the bottom of a $150 \times 16 \mathrm{~mm}$ test tube and the acetone was removed by a stream of $\mathrm{CO}_{2}$. Reduced sterile CRF ( $\left.1 \cdot 5 \mathrm{ml}\right)$ was added, $\mathrm{CO}_{2}$ was bubbled for a further I min and then the tube was stoppered. The inducer fraction was dispersed ultrasonically in the rumen fluid by immersion to the level of the liquid in the tube in an ultrasonic cleaning bath (Kerry, Basildon, Essex) for 2 min. The rumen fluid fraction $(2.5 \mathrm{ml}$; prepared from rumen fluid obtained from a sheep devoid of phycomycetes) under test was added and the mixture was incubated under $\mathrm{CO}_{2}$ at $39^{\circ} \mathrm{C}$. A series of such tubes was prepared and incubation was terminated after 1 or $2 \mathrm{~h}$. The contents were assayed quantitatively for inducer.

Detection and assay of inducer in rumen fluid supernatant fraction. Rumen fluid, obtained by aspiration, was filtered quickly through a layer of muslin, cooled to $0^{\circ} \mathrm{C}$ and centrifuged at $38500 \mathrm{~g}$ for $\mathrm{I} \mathrm{h}$ to remove rumen bacteria and plant particles. The inducer activity in the supernatant liquid was assayed by incubating I $\mathrm{ml}$ dilutions (using rumen fluid supernatant taken before feeding as diluent) with I $\mathrm{ml}$ fresh FRF taken $20 \mathrm{~h}$ after feeding. The population density of the flagellates was recorded before and after 30 min incubation at $39{ }^{\circ} \mathrm{C}$ under $\mathrm{CO}_{2}$. The relative quantity of inducer present was calculated by plotting the dilution against flagellate production as described above.

Estimation of inducers in rumen fuid particulate fraction. The methods of Orpin $(1975,1976,1977 b)$ were used to isolate the inducer fractions. The inducer was assayed by the method used for inducer extracted from plant tissues.

Ultrafiltration. The initial $80 \%(\mathrm{v} / \mathrm{v})$ aqueous acetone extract (after removing the acetone under reduced pressure) was ultrafiltered through a membrane with a cut-off at 10000 daltons (UMIO Diaflo membrane held in an Amicon model 12 cell; Amicon, High Wycombe, Buckinghamshire). Operations were performed under $\mathrm{N}_{2}$ and $0.02 \%$ L-cysteine hydrochloride (freshly neutralized with $0 . \mathrm{I} \mathrm{M}-\mathrm{NaOH}$ ) was added to the extract to minimize oxidation. The inducer activity in the filtrate was determined quantitatively and compared with that in the original extract.

Purification of inducer. The diethyl ether extract $(50 \mathrm{ml})$ was washed three times with $50 \mathrm{ml} 2 \%(\mathrm{w} / \mathrm{v})$ sodium bicarbonate. The aqueous phase was acidified with $6 \mathrm{M}-\mathrm{HCl}$ to $\mathrm{pH} 6.0$ and extracted three times with an equal volume of diethyl ether. This ether extract was evaporated under reduced pressure at less than $40^{\circ} \mathrm{C}$ to about $50 \mathrm{ml}$ and was shaken three times with sodium phosphate buffer $(0.067 \mathrm{M}, \mathrm{pH} 7.8$, $50 \mathrm{ml}$ ). The inducer in the residual ether extract and in each aqueous fraction ( $\mathrm{pH}$ adjusted to 7.0 where necessary) was assayed quantitatively for each inducer.

\section{RESULTS}

Stability of inducers in whole oats. To monitor the change in the inducing capacity of oats during storage, samples of a batch of oats were stored at different temperatures and under various gas phases for different times. For $N$. frontalis, the activity of the inducer decreased during storage of the oats except when stored at $-20^{\circ} \mathrm{C}$. Low storage temperatures and the absence of oxygen increased the survival time of the inducer (Fig. I). Results with the inducers of zoosporogenesis in $S$. communis and $P$. communis were similar (not shown).

Since the activity of the inducer in whole oats decreased during storage, and the amount of inducer varied between different batches of oats (six batches were measured, showing variation between 72 and II $4 \%$ of the standard extract), a standard extract was prepared from $2 \mathrm{~kg}$ of a single batch of oats and stored in $5 \mathrm{ml}$ quantities under $\mathrm{N}_{2}$ at $-20^{\circ} \mathrm{C}$. This extract was used routinely as a reference standard when determining the relative concentrations of the inducers in other plant tissues.

Stability of inducers in vitro. Varying the $\mathrm{pH}$, heat and gas phases showed that the activity of the inducers was almost completely destroyed on heating at $100{ }^{\circ} \mathrm{C}$ for $5 \mathrm{~min}$ in the presence of oxygen, but not when heated under anaerobic conditions (Table I). This loss of activity was independent of the $\mathrm{pH}$. Little loss of activity occurred aerobically at $22{ }^{\circ} \mathrm{C}$ after $\mathrm{I} \mathrm{h}$, although after $8 \mathrm{~h}$ activity was eliminated. Inducer preparations stored under $\mathrm{N}_{2}$ at $-20^{\circ} \mathrm{C}$ lost none of their activity during 3 months of storage. No loss of activity occurred when the inducer was heated aerobically at $100^{\circ} \mathrm{C}$ at $\mathrm{pH} 4$ for $5 \mathrm{~min}$ in the presence of $0.02 \% \mathrm{~L}$-cysteine hydrochloride.

Effect of rumen micro-organisms. The activity of each inducer was rapidly destroyed by 

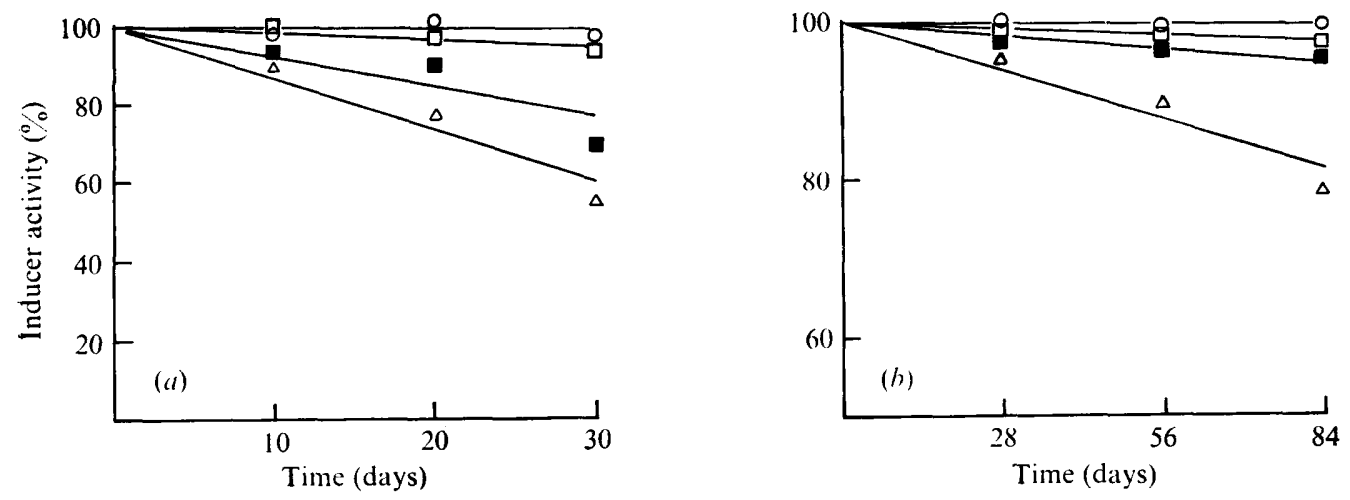

Fig. I. Effect of conditions of storage on $N$. frontalis inducer content of whole oats. Whole oats were stored under different conditions of aerobiosis and temperature; samples were removed at intervals and assayed for inducer activity. Inducer activity is expressed as the percentage of that present at the start of the experiment. The oats were stored in $(a)$ air and $(b)$ nitrogen at $39^{\circ} \mathrm{C}(\triangle)$, $25{ }^{\circ} \mathrm{C}(\square), 4{ }^{\circ} \mathrm{C}(\square)$ and $-20^{\circ} \mathrm{C}(\mathrm{O})$.

Table I. Effect of heat, gas phase and pH on the capacity of the inducers to stimulate flagellate production

Results are expressed as the increase in the population density $\mathrm{ml}^{-1} \times 10^{-2}$ of each flagellate species after incubation under $\mathrm{CO}_{2}$ at $39^{\circ} \mathrm{C}$ with inducer extracted from $200 \mathrm{mg}$ dry wt oats, pretreated under different conditions.

\begin{tabular}{|c|c|c|c|c|c|c|}
\hline \multicolumn{4}{|c|}{ Pretreatment } & \multicolumn{3}{|c|}{ Flagellate production } \\
\hline Temp. & $\begin{array}{c}\text { Incubation } \\
\text { time }\end{array}$ & $\mathrm{pH}$ & Gas phase & $\begin{array}{c}N . \\
\text { frontalis }\end{array}$ & $\begin{array}{c}P . \\
\text { communis }\end{array}$ & $\underset{\text { communis }}{S .}$ \\
\hline \multirow[t]{3}{*}{$22^{\circ} \mathrm{C}$} & $\mathrm{I} \cdot \mathrm{O} \mathrm{h}$ & $\begin{array}{l}4.0 \\
9.0\end{array}$ & $\begin{array}{l}\mathrm{O}_{2} \\
\mathrm{O}_{2}\end{array}$ & $\begin{array}{l}85 \\
88\end{array}$ & $\begin{array}{l}102 \\
109\end{array}$ & $\begin{array}{l}54 \\
58\end{array}$ \\
\hline & & $7 \cdot 0$ & $\begin{array}{l}\mathrm{Air} \\
\mathrm{O}_{2} \\
\mathrm{~N}_{2} \\
\mathrm{CO}_{2}\end{array}$ & $\begin{array}{r}91 \\
82 \\
98 \\
102\end{array}$ & $\begin{array}{r}102 \\
96 \\
130 \\
138\end{array}$ & $\begin{array}{l}60 \\
62 \\
75 \\
70\end{array}$ \\
\hline & $\begin{array}{l}4.0 \mathrm{~h} \\
8.0 \mathrm{~h}\end{array}$ & $\begin{array}{l}7 \cdot 0 \\
7 \cdot 0\end{array}$ & $\begin{array}{l}\text { Air } \\
\text { Air }\end{array}$ & $\begin{array}{r}47 \\
0\end{array}$ & $\begin{array}{r}32 \\
0\end{array}$ & $\begin{array}{r}23 \\
0\end{array}$ \\
\hline \multirow[t]{3}{*}{$100{ }^{\circ} \mathrm{C}$} & $5 \mathrm{~min}$ & $4 \cdot 0$ & $\begin{array}{l}\mathrm{O}_{2} \\
\mathrm{~N}_{2} \\
\mathrm{CO}_{2}\end{array}$ & $\begin{array}{r}4 \\
98 \\
102\end{array}$ & $\begin{array}{r}15 \\
135 \\
148\end{array}$ & $\begin{array}{r}0 \\
65 \\
82\end{array}$ \\
\hline & & $7 \cdot 0$ & $\begin{array}{l}\mathrm{O}_{2} \\
\mathrm{~N}_{2} \\
\mathrm{CO}_{2}\end{array}$ & $\begin{array}{r}2 \\
93 \\
96\end{array}$ & $\begin{array}{r}6 \\
147 \\
159\end{array}$ & $\begin{array}{r}0 \\
80 \\
85\end{array}$ \\
\hline & & $9 \cdot 0$ & $\begin{array}{l}\mathrm{O}_{2} \\
\mathrm{~N}_{2} \\
\mathrm{CO}_{2}\end{array}$ & $\begin{array}{r}2 \\
94 \\
90\end{array}$ & $\begin{array}{r}10 \\
135 \\
145\end{array}$ & $\begin{array}{r}3 \\
72 \\
70\end{array}$ \\
\hline Contro & reated & & & 109 & 152 & 77 \\
\hline
\end{tabular}

the rumen bacteria but relatively little destruction occurred with the protozoal (large particulate) and soluble fractions (CRF) of fresh rumen fluid (Table 2). No significant destruction occurred in the presence of the same fractions which had been boiled, or in autoclaved FRF, indicating that a physical or chemical reaction was not responsible for the loss of activity.

Distribution of inducers in different plant species. The inducers of sporogenesis of 
Table 2. Effect of incubation with different rumen fuid fractions on the activity of the inducer components of oats

Inducer from $300 \mathrm{mg}$ dry wt oats was dried on to the bottom of $150 \times 16 \mathrm{~mm}$ test tubes under $\mathrm{CO}_{2}$ and dispersed ultrasonically in $1.5 \mathrm{ml}$ reduced sterile CRF. The rumen fluid fraction (2.5 $\left.\mathrm{ml}\right)$, devoid of phycomycetes, was added and the tubes were incubated under $\mathrm{CO}_{2}$ at $39{ }^{\circ} \mathrm{C}$ for up to $2 \mathrm{~h}$. The inducer was then assayed quantitatively. Results are expressed relative to the inducer present at zero time $(=100)$.

\begin{tabular}{|c|c|c|c|c|c|c|c|}
\hline & & & & & & & \\
\hline & & $N$ & alis & $P . c$ & Inis & S. $c$ & unis \\
\hline $\begin{array}{l}\text { Time of incubation }(h) \\
\text { Fraction }\end{array}$ & $\cdots$ & I $\cdot 0$ & $2 \cdot 0$ & $I \cdot 0$ & $2 \cdot 0$ & $1 \cdot 0$ & $2 \cdot 0$ \\
\hline Filtered rumen fluid & & 15 & 0 & 0 & 0 & 0 & 0 \\
\hline Large particulate & & 85 & 75 & 60 & 43 & 52 & 28 \\
\hline Bacteria & & 19 & 0 & 22 & 0 & 15 & 0 \\
\hline CRF & & 98 & 93 & 90 & 98 & 87 & 82 \\
\hline Filtered rumen fluid (autoclaved) & & 92 & 98 & 102 & 94 & 94 & 96 \\
\hline
\end{tabular}

Table 3. Distribution of each inducer in leaves of different plant species

Dried leaves of each species (I $\mathrm{g}$ ) were extracted with $20 \mathrm{ml} 80 \%$ aqueous acetone, evaporated to near dryness in vacuo and taken up in acetone ( $1.0 \mathrm{ml})$. The extract was then assayed quantitatively for each inducer. Results are expressed relative to the quantity of inducer present in the standard oats extract $(=100)$.

Family
Pinaceae
Papaveraceae
Cruciferae
Tiliaceae
Aceraceae
Papilionaceae

Rosaceae
Onograceae
Polygonaceae
Urticaceae
Compositae
Gramineae

$\quad$ Species
Pinus sylvestris $\mathrm{L}$.
Papaver rhoeas $\mathrm{L}$.
Brassica napus $\mathrm{L}$.
Tilia platyphyllos Scop.
Acer pseudoplatanus $\mathrm{L}$.
Medicago sativa $\mathrm{L}$.
Trifolium pratense $\mathrm{L}$.
Trifolium repens $\mathrm{L}$.
Rubus fructicosus $\mathrm{L}$.
Epilobilim hirsutum $\mathrm{L}$.
Rumex sanguineus $\mathrm{L}$.
Urtica dioica $\mathrm{L}$.
Taraxacum officionale Weber
Festuca ovina agg.
Lolium perenne $\mathrm{L}$.
Poa pratensis $\mathrm{L}$.
Dactylis glomerata L.
Hordeum distichon (barley)
Avena sativa (oats)
Triticum aestivum (wheat)

NT, Not tested.

\begin{tabular}{ccc}
\multicolumn{3}{c}{ Inducer $(\mathrm{g} \mathrm{dry} \mathrm{wt)})^{-1}$} \\
$\begin{array}{c}\text { N. } \\
\text { frontalis }\end{array}$ & $\begin{array}{c}P . \\
\text { communis }\end{array}$ & $\begin{array}{c}S . \\
\text { communis }\end{array}$ \\
55 & 47 & $\mathrm{NT}$ \\
96 & 70 & $\mathrm{I} 10$ \\
84 & 72 & 70 \\
18 & 28 & $\mathrm{NT}$ \\
30 & 24 & 14 \\
72 & 56 & 66 \\
104 & 92 & 74 \\
96 & 72 & 84 \\
0 & 0 & 0 \\
0 & 0 & 0 \\
77 & 66 & 60 \\
106 & 115 & 92 \\
88 & 70 & 68 \\
127 & 93 & 106 \\
185 & 147 & 142 \\
166 & 160 & 157 \\
195 & 198 & 210 \\
180 & 174 & 196 \\
196 & 206 & 208 \\
170 & 163 & 177 \\
& &
\end{tabular}

$N$. frontalis, $S$. communis and $P$. communis were present in a wide variety of plants (Table 3 ). There appeared to be no taxonomic relationship between plants which possessed inducer activity, or in which it was absent. However, if activity was present then all three species responded at a similar level. Of the plants tested, all members of the Gramineae (grasses) contained consistently high levels of the inducers.

Distribution of inducers in different tissues of Lolium perenne L. (perennial rye-grass) and Hordeum distichon (barley). Inducer activity for the three species of rumen phycomycetes was present in all of the aerial tissues of these plants; little occurred in the root tissues. 
Table 4. Distribution of inducers in tissues of Lolium perenne $L$.

Dried tissue (I g) was extracted with $80 \%$ aqueous acetone and evaporated to near dryness in vacuo. The residue was taken up in acetone $(1 \mathrm{ml})$ and assayed quantitatively for inducer content. The soluble and insoluble leaf fractions were prepared by homogenizing fresh tissue ( $1.5 \mathrm{~g} \mathrm{dry} \mathrm{wt)}$ and separating the solids by centrifugation $\left(38000 \mathrm{~g}, 30 \mathrm{~min}, 4^{\circ} \mathrm{C}\right)$. The fractions were assayed for inducer content separately. Results are expressed relative to the quantity of inducer present in the standard oats extract $(=100)$.

Tissue

Mature leaves

Stem

Root

Inflorescence

Seedhead

Leaf, soluble

Leaf, insoluble

Leaf, young (two-leaf stage)
Inducer ( $\mathrm{g}$ dry wt tissue) $)^{-1}$

$\begin{array}{ccc}N . \text { frontalis } & P \text {. communis } & S \text {. communis } \\ 210 & 204 & 210 \\ 60 & 54 & 72 \\ 51 & 45 & 54 \\ 120 & 135 & 128 \\ 86 & 82 & 70 \\ 166 & 174 & 152 \\ 29 & 44 & 62 \\ 264 & 238 & 293\end{array}$

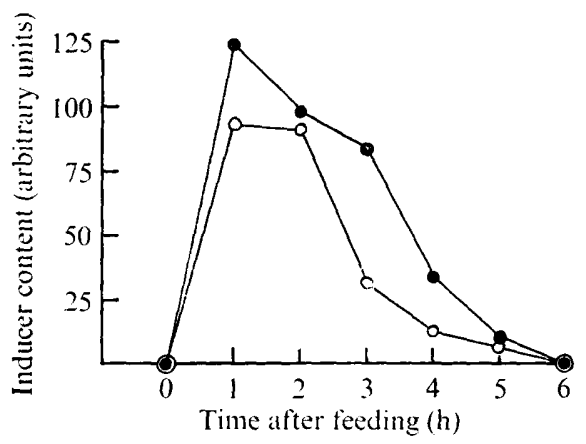

Fig. 2

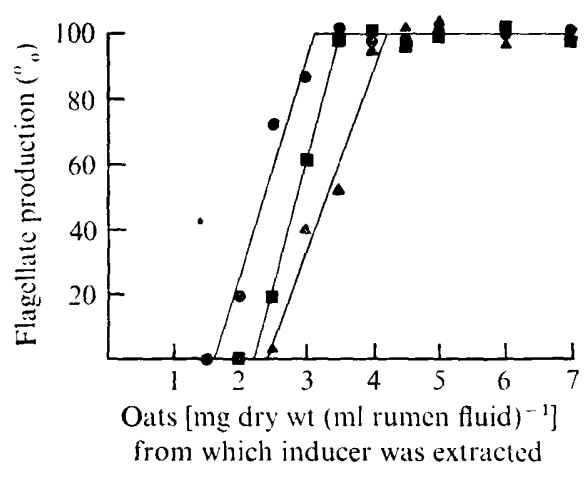

Fig. 3

Fig. 2. Persistence of inducer of $N$. frontalis in rumen fluid supernatant $(O)$ and particulate $(O)$ fractions. Samples of rumen fluid were taken immediately before feeding and at hourly intervals afterwards. The fluid was centrifuged at $38500 \mathrm{~g}$ for $\mathrm{I} \mathrm{h}$ and the supernatant fluid and the sedimented particulate material were each assayed for inducer content. The inducer content was expressed relative to that present in the standard extract of oats $(=100)$.

Fig. 3. Effect of oats extract on zoosporogenesis in $N$. frontalis ( $), P$. communis ( $\square$ ), and $S$. communis $(\mathbf{\Delta})$. The standard extract of oats was serially diluted and each dilution, representing the extract from a known weight of dry oats, was assayed for its ability to stimulate flagellate production in filtered rumen fluid in vitro. Results are expressed as a percentage of the flagellates liberated by the standard extract containing inducer from $100 \mathrm{mg}$ dry wt oats $\mathrm{ml}^{-1}$.

More inducer was present in young plants, and more was present in the leaves than in the stems, inflorescence or seedhead, when compared on a dry weight basis (Table 4). Results with barley were similar to those obtained with $L$. perenne. The inducers were released into the supernatant fluid after homogenization of the leaves, indicating that they were probably present in the cell contents rather than associated with the cell walls.

Survival in rumen contents. No inducer activity could be extracted from the rumen particulate fraction prior to feeding the host animal, nor 5 to $6 \mathrm{~h}$ after feeding. Between these times, active inducer was present in the rumen fluid particulate material. Release of inducer into the rumen fluid supernatant was highest during the first $2 \mathrm{~h}$ after feeding. The results for $N$. frontalis are given in Fig. 2; those for $P$. communis and $S$. communis were similar (not shown) although the inducer of $S$. communis was not detected in either fraction $5 \mathrm{~h}$ after feeding. 




\begin{tabular}{crrrr} 
Fraction & \multicolumn{1}{c}{ (a) } & $(b)$ & & \\
1 & 100 & 100 & 100 & 100 \\
2 & 8 & 10 & 1 & 5 \\
3 & 75 & 78 & 67 & 65 \\
4 & 43 & 52 & 34 & 38 \\
5 & 7 & 7 & 2 & 8 \\
6 & 4 & 2 & 6 & 4 \\
7 & 20 & 28 & 19 & 22 \\
8 & 0 & 0 & 0 & 0 \\
9 & 10 & 15 & 10 & 8
\end{tabular}

Fig. 4. Purification of inducers using solvent extraction. Whole oats were extracted with $80 \%$ (v/v) aqueous acetone, and the acetone was removed under reduced pressure at less than $40^{\circ} \mathrm{C}$. The aqueous residue was extracted as shown in the scheme. Each fraction was assayed quantitatively for inducer for each species of phycomycete. Results are expressed as the percentage of each inducer present compared with that in the aqueous residue. Analar diethyl ether was used during the extraction of $P$. communis, $S$. communis and $N$. frontalis $(a)$ inducers. For the purification of $N$. frontalis $(b)$ inducer, the diethyl ether was distilled over reduced iron powder to render it peroxide-free and I mM-mercaptoethanol was incorporated into the aqueous phase.

Dietary requirements for complete zoosporogenesis of rumen phycomycetes. To ascertain the minimum quantity of inducer that induced zoosporogenesis in the entire population of each species of phycomycete in the rumen, samples of rumen fluid containing each species as the sole phycomycete were exposed to inducer extracted from different quantities of oats. Neocallimastix frontalis was sensitive to inducer extracted from as little as $\mathrm{I} \cdot 6 \mathrm{mg}$ oats per $\mathrm{ml}$ rumen fluid but only showed total zoosporogenesis in the presence of inducer extracted from 3. I mg oats per $\mathrm{ml}$ rumen fluid (Fig. 3). Therefore, for a rumen fluid volume of $5 \mathrm{l}$, inducer from $15.5 \mathrm{~g}$ dry wt oats would be necessary for total induction. The values for $P$. communis were $2.4 \mathrm{mg}, 3.5 \mathrm{mg}$ and $17.5 \mathrm{~g}$ respectively. More inducer was required in vivo than in vitro for total zoosporogenesis. In vivo, inducer extracted from more than 25,28 and $30 \mathrm{~g}$ dry wt oats was necessary for the total induction of $N$. frontalis, $P$. communis 
and $S$. communis flagellate production respectively. The reason for this was not clear, but may be related to mixing problems in the rumen. Knowing the quantity of inducers in different plant species and tissues relative to that in the standard oats extract, the minimum intake of these plants tissues which would result in total zoosporogenesis in each species of phycomycete was calculated (i) as the minimum dry weight of tissue to produce total zoosporogenesis in a rumen of 51 and (ii) as the maximum dry weight of tissue eliciting no detectable response in a rumen of 51 . The values for the inducer of $N$. frontalis in L. perenne were: at the two-leaf stage, (i) $5.5 \mathrm{~g}$, (ii) $3.0 \mathrm{~g}$; for mature leaves, (i) $7.35 \mathrm{~g}$, (ii) $3.80 \mathrm{~g}$; for hay, (i) $28 \cdot 7 \mathrm{~g}$, (ii) $14.8 \mathrm{~g}$; and for thrashed seed hay, (i) $44.3 \mathrm{~g}$, (ii) $22.8 \mathrm{~g}$.

Ultrafiltration. During these experiments some inducer was lost even though anaerobic techniques were used when possible. The majority of the activity passed through the ultrafilter indicating that the molecular weights of the inducers were less than I0000. The total recoveries of inducer in the ultrafiltrate (expressed as a percentage of that present in the original extract) for $N$. frontalis, $P$. communis and $S$. communis were $7 \mathrm{I}, 63$ and $6 \mathrm{I}$ respectively.

Vitamins. The low molecular weight, low apparent quantity required in the diet to stimulate zoosporogenesis and instability suggested that the inducers could possibly be vitamins. Ascorbic acid, folic acid, $d l$-L-tetrahydrofolic acid, riboflavin, pyridoxine hydrochloride, biotin, pantothenic acid, thiamin hydrochloride and cyanocobalamin were each tested separately for inducer activity at I $\mathrm{mm}$ using the standard qualitative assay with the vitamin replacing the inducer. No significant flagellate production was detected for any species with any of the compounds tested.

Solvent extraction. Up to $90 \%$ of the inducer activity was lost during solvent extraction even if peroxide-free diethyl ether was used and I mM-mercaptoethanol was incorporated into the aqueous phase. Mercaptoethanol did not inhibit zoosporogenesis. The results (Fig. 4) show that the inducers were soluble in diethyl ether at $\mathrm{pH}$ values below $7 \cdot 8$, and were soluble in sodium bicarbonate ( $\mathrm{pH} \mathrm{8.2).} \mathrm{Attempts} \mathrm{to} \mathrm{chromatograph} \mathrm{the} \mathrm{final} \mathrm{ether}$ extract on thin layers of silica gel $G$ or cellulose powder $(300 \mathrm{~mm})$ resulted in a loss of activity before or during chromatography even in a nitrogen atmosphere.

\section{DISCUSSION}

Although the identities of the dietary compounds which stimulate zoosporogenesis in $N$. frontalis, $P$. communis and $S$. communis are unknown they are widely distributed in plants. Most of the species tested (including herbaceous and woody plants) contained them and there appears to be no taxonomic relationship in their occurrence. The relative quantities present in the leaves of different plants varied considerably but representatives of the Gramineae consistently showed the highest levels. Two other plants that are frequently present in pastures in Great Britain, Trifolium repens and Trifolium pratense, also contained high levels, as did several common weed species, notably Rumex sanguineus, Urtica dioica and Taraxacum officionale, to which ruminants are likely to have access when at pasture. Since grasses (including hay) and cereals are a major dietary component of ruminants it follows that under the majority of feeding regimes the inducers enter the rumen each time the animal eats. The only foreseeable conditions under which no inducer would enter the rumen would be in a diet consisting of materials stored for a long time under hot aerobic conditions. If loss of inducer in oats continued at the same rate as in Fig. I $(a)$, at $25^{\circ} \mathrm{C}$ all inducer would be lost after 8 months. All normal diets should contain an excess of inducer sufficient to trigger zoosporogenesis in all the sporangia in the population of mature vegetative growths of each species of phycomycete. The sensitivity of the sporangia to the inducers ensures that the flagellates are released at a time when fresh, nutrient rich, plant tissue is present in the rumen, ensuring maximum growth of the vegetative phases of the organisms. Flagellates of $N$. frontalis and $P$. communis are known 
to invade inflorescence tissue in the rumen with subsequent growth of the vegetative stage on that tissue (Orpin, 1977a, b). This tissue would be present at the time of flagellate release and would not have been substantially metabolized by the other rumen microorganisms. Since the inducers are present in the soluble cell contents, release would occur during initial chewing by the host animal (Reid, Lyttleton \& Mangan, 1962) and subsequent chewing of the cud. Some inducer is released during soaking in aqueous solution (Orpin, 1974) so it would also be released in the rumen from tissues undamaged by mastication.

The inducers have molecular weights of less than 10000 and their characteristics during partition between diethyl ether and aqueous solutions at different $\mathrm{pH}$ values indicate that they are acidic compounds with a $\mathrm{p} K_{\mathrm{a}}$ of 7.8 to 8.2 . This rules out the possibility that they are simple sugars, common amino acids or fatty acids. The possibility that the inducers may be a common vitamin has also been ruled out by specific assays.

The stability and $\mathrm{p} K_{\mathrm{a}}$ of the inducer of each species of phycomycete, and the distribution of each inducer in different plant species and tissues was almost identical. In all cases the stabilities both in vivo and in vitro of the inducers of sporogenesis were so alike as to suggest that the three inducers may be similar, perhaps identical, compounds. Work designed to identify these compounds is currently under way.

I thank Dr P. Kemp for cannulating the sheep, and Miss A. L. Lowings and Mrs M. Fordham for technical assistance.

\section{REFERENCES}

Abou Akkada, A. R., Bartley, E. E., Berube, R., FinA, L. R., MeYer, R. M., Hendricks, D. \& Julius, F. (1968). Simple method to remove completely ciliate protozoa from adult ruminants. Applied Microbiology r6, 1475-1477.

ORPIN, C. G. (1974). The rumen flagellate Callimastix frontalis: does sequestration occur? Journal of General Microbiology 84, 395 398.

ORPIN, C. G. (1975). Studies on the rumen flagellate Neocallimastix frontalis. Journal of General Microbiology 91, 249-262.

ORPIN, C. G. (1976). Studies on the rumen flagellate Sphaeromonas communis. Journal of General Microbiology 94, 270-280.

OrPIN, C. G. (1977a). Invasion of plant tissue in the rumen by the flagellate Neocallimastix frontalis. Journal of General Microbiology 98, 423-430.
OrPIN, C. G. (I977b). The rumen flagellate Piromonas communis: its life-history and invasion of plant material in the rumen. Journal of General Microbiology 99, 107-117.

OrPIN, C. G. (I977c). The occurrence of chitin in the cell walls of the rumen organisms Neocallimastix frontalis, Piromonas communis and Sphaeromonas communis. Journal of General Microbiology 99, 21 5-218.

Reid, C. S. W., Lyttletch, J. W. \& Mangan, J. L. (1962). Bloat in cattle. XXIV. A method of measuring the effectiveness of chewing in the release of plant cell contents from ingested feed. New Zealand Journal of Agricultural Research 5 , 237-248. 